\title{
GLUTATHIONE IN THE BLOOD IN SENILE CATARACT AND OTHER OCULAR CONDITIONS
}

\author{
BY \\ Dorothy Adams Campbell \\ BIRMINGHAM
}

\section{Introduction}

IT is well known that the human lens is rich in glutathione and that this substance disappears totally from the lens in senile cataract. Glutathione is remarkable in being the most labile sulphur-containing substance in the body. It is, as we know, closely associated with tissue respiration, which assumes special importance in a non-vascular tissue such as the lens. The relation of glutathione to the general sulphur metabolism of the body has never been determined (Lewis), either in the normal subject or in disease. As a first step towards this investigation it was thought worth while to estimate the blood glutathione in cases of senile cataract and other ocular disease, the range for blood glutathione in the normal being already well known. In addition, in some concurrent investigations (Bourne and Campbell), a study was made of the sulphur metabolism in the same types of patients, by giving diets of known sulphur value and estimating the corresponding sulphur excretion in the urine. The figures obtained from the two series of experiments provide an interesting first record of the relation of blood glutathione to sulphur metabolism, particularly in senile cataract as compared with other ocular disease. In actual fact, the sulphur metabolism in these cases was not found to be abnormal, as might have been expected.

\section{Historical}

The bulk of the glutathione present in the blood is in the reduced form, which varies from $25-41 \mathrm{mgm}$. per 100 c.c. (average 34), while the oxidised form varies from 3-11 mgm. (Woodward and Fry). This is in agreement with the earlier observations for reduced glutathione in the normal subject-Benedictand Gottschall 30-48, Mason 36-58, Achard, Levy and Guthmann 36-58 and Groen and Meyer $40 \mathrm{mgm}$. It is wholly contained in the corpuscles, and if considered in relation to the blood count, the factor, reduced glutathione, red cell count, ranges from 4.9-9.1 (Woodward and Fry).

Little is known as to the variation of glutathione in disease. Achard, Levy and Guthmann (1932) found a slight decrease in anaemia, diabetes, neoplasm and tuberculosis, while Giordano and 
Battistini (1933) found no variation in a number of diseases. Senturia (1934) states that there is no variation from the normal in cases of arthritis, while Loomis and Bogen (1934) found a slight increase in the reduced form, and a decrease in the oxidised, in tubercle, which they ascribed to defective aeration of the blood. Oberst and Woods (1935) recently estimated the blood glutathione in 66 women.

The only figures availabie for patients with ocular disease, are those of Vele (1933), who employed an older and rather less accurate method of estimation. For normal patients, she found a range of only $13.5-24.5 \mathrm{mgm}$. per 100 c.c. (average 18.25 ), whereas in a large variety of ocular disease she found an increase in every type of case, ranging from $15-60 \mathrm{mgm}$. She states that there was an accompanying rise in the red cell count, and whereas the factor GSH/r.b.c. was 4 in the normal, it was 6-8 in ocular disease, and even higher in keratitis.

\section{Experimental}

The usual methods for the estimation of glutathione were based on the reduction of iodine, but in the last few years, reducing substances other than gutathione have been shown to be present in the tissues, e.g., thionine and ascorbic acid (Vitamin C), which interfere with the estimation. Thus in the ox lens, $1 / 5$ of the total reduction of iodine by a trichloracetic acid filtrate, formerly ascribed wholly to glutathione, is due to Vitamin $C$, and in the case of a human lens from a 30 -year-old subject, 28 per cent. of the reduction was due to Vitamin C. (Euler and Martius.)

For the present series of estimations, therefore, the method of Woodward and Fry (1932) was used, in which the interference from other substances is very small. Thus the amount of thionine in the blood could cause at the most an error of $3 \mathrm{mgm}$. per cent., while Vitamin $C$ is present in the reduced form to the extent of only $0.5 \mathrm{mgm}$. per 100 c.c. blood. One slight variation was made in the method, viz., in order to obtain the figure for total glutathione, reduction of the solution with zinc was carried out at $37^{\circ} \mathrm{C}$. instead of at room temperature.

In every case, samples of venous blood were analysed immediately after withdrawal, the blood being taken not less than two hours and a half after a meal. As the range of glutathione has been adequately demonstrated for the normal, the estimations on patients with senile cataract were compared with those from cases of other ocular disease, exclusive of any condition affecting the lens. In cataract patients, the blood was taken at a time when there was no active absorption of lens matter in progress, i.e., after a preliminary iridectomy when the lens had not been 
disturbed, or some time after an extraction when no residual cortex was present.

With very few exceptions the patients were under observation in hospital, and it was possible to study a number on a strictly balanced diet of known calorie value, for three successive days. A comparison of the blood glutathione was made in the two classes of patients (a) senile cataract, (b) ocular disease exclusive of cataract, as follows :-

(1) On ordinary hospital diet, uncontrolled.

(2) On controlled normal diet of known calorie value and sulphur intake.

(3) In relation to the red cell count, on ordinary diet.

(4) In relation to the red cell count, on controlled high protein, low protein and normal diets of the same calorie values.

An example is given of the controlled normal diet of 2,347 calories which was most used, and details of the high and low protein (i.e., high and low sulphur) diets can be found elsewhere, in a full description of the investigation of the sulphur metabolism in these patients (Bourne and Campbell). The results are summarised in the following tables. The abbreviations "GSH" and "GSSG" are used to signify reduced and oxidised glutathione respectively. The sulphur and protein values of foodstuffs were taken from Sherman's " Chemistry of Food and Nutrition," 1933.

\section{TABLE I}

Blood Glutathione, Reduced and Oxidised, in Patients on ordinary Hospital DieT

\begin{tabular}{|c|c|c|c|c|c|}
\hline Patient & Sex & Age & $\begin{array}{r}\text { GSH } \\
\text { lmgm.per }\end{array}$ & $\begin{array}{l}\text { GSSG } \\
\text { c.c. blood }\end{array}$ & Clinical details \\
\hline \multirow[t]{2}{*}{$\begin{array}{ll}\text { C. C. } & \ldots \\
\text { W. S. } & \cdots \\
\text { M. T. } & \cdots \\
\text { L. S. } & \cdots \\
\text { H. A. } & \cdots\end{array}$} & \multirow[t]{2}{*}{$\begin{array}{l}\text { M. } \\
\text { M. } \\
\text { F. } \\
\because \\
M\end{array}$} & \multirow[t]{2}{*}{$\begin{array}{l}56 \\
71 \\
71 \\
75 \\
75\end{array}$} & $\begin{array}{l}50 \cdot 15 \\
38 \cdot 95 \\
35 \cdot 12 \\
53 \cdot 37 \\
51 \cdot 21\end{array}$ & $\begin{array}{l}2 \cdot 40 \\
3 \cdot 58 \\
2 \cdot 29 \\
183 \\
2 \cdot 16\end{array}$ & \multirow[t]{2}{*}{ Senile cataract } \\
\hline & & & $45 \cdot 76$ & $2 \cdot 45$ & \\
\hline \multirow[t]{2}{*}{$\begin{array}{l}\text { C. B. } \\
\text { G. C. } \\
\text { P. } \\
\text { H. B. } \\
\text { L. F. } \\
\text { A. C. } \\
\text { J. L. } \\
\text { E. J. }\end{array}$} & \multirow[t]{2}{*}{$\begin{array}{c}\text { F. } \\
\text { M. } \\
\text { F. } \\
\text { M. } \\
\text { F. } \\
\text { M. } \\
\text { M. } \\
\text { F. }\end{array}$} & $\begin{array}{r}9 \\
9 \\
33 \\
43 \\
52 \\
58 \\
62 \\
71\end{array}$ & $\begin{array}{l}39 \cdot 87 \\
32 \cdot 82 \\
36 \cdot 19 \\
41 \cdot 10 \\
38 \cdot 95 \\
45 \cdot 70 \\
46 \cdot 01 \\
36 \cdot 80\end{array}$ & $\begin{array}{l}0.00 \\
3.06 \\
4.91 \\
0.91 \\
6.14 \\
1.23 \\
0.91 \\
3.99\end{array}$ & \multirow[t]{2}{*}{$\begin{array}{l}\text { Strabismus } \\
\text { Strabismus } \\
\text { Perforating in jury, L.E. } \\
\text { Specific iritis, R. and L. } \\
\text { Lacrimal abscess } \\
\text { L. excision, choroidal sarcoma } \\
\text { Glaucoma, R. and L. } \\
\text { Secondary glaucoma, L.E. } \\
\text { Average }\end{array}$} \\
\hline & & & $39 \cdot 68$ & $2 \cdot 84$ & \\
\hline & & 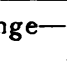 & $\begin{array}{l}12-53 \cdot 37 \\
82-46 \cdot 01\end{array}$ & $\begin{array}{l}1 \cdot 83-3 \cdot 58 \\
0 \cdot 00-6 \cdot 14\end{array}$ & $\begin{array}{l}\text { enile cataract } \\
\text { on-cataract cases. }\end{array}$ \\
\hline
\end{tabular}


TABLE II

Blood Glutathione in Patients on Controlled Normal Diet

\begin{tabular}{|c|c|c|c|c|c|c|}
\hline Patient & Sex & Age & $\begin{array}{c}\text { Diet } \\
\text { Calories }\end{array}$ & $\begin{array}{r}\text { GSH } \\
\text { mgm. per }\end{array}$ & $\begin{array}{l}\text { GSSG } \\
\text { c.c. blood }\end{array}$ & Clinical details \\
\hline \multirow[t]{2}{*}{ 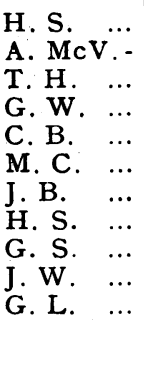 } & \multirow[t]{2}{*}{$\begin{array}{l}\text { F. } \\
\text { F. } \\
\text { M. } \\
\text { M. } \\
\text { F. } \\
\text { F. } \\
\text { M. } \\
\text { M. } \\
\text { M. } \\
\text { M. } \\
\text { F. }\end{array}$} & \multirow[t]{2}{*}{$\begin{array}{l}43 \\
51 \\
54 \\
55 \\
57 \\
57 \\
65 \\
67 \\
68 \\
69 \\
79\end{array}$} & $\begin{array}{l}2495 \\
2347 \\
2347 \\
2347 \\
2347 \\
2178 \\
2347 \\
2347 \\
2347 \\
2347 \\
2393\end{array}$ & $\begin{array}{l}3979 \\
36 \cdot 80 \\
36 \cdot 96 \\
38 \cdot 34 \\
37 \cdot 42 \\
46 \cdot 01 \\
41 \cdot 01 \\
41 \cdot 71 \\
49 \cdot 69 \\
46 \cdot 01 \\
44 \cdot 01\end{array}$ & $\begin{array}{l}6.22 \\
- \\
0.46 \\
1.53 \\
1.84 \\
6.41 \\
3.05 \\
4.30 \\
3.99 \\
0.89 \\
-\end{array}$ & Senile cataract \\
\hline & & & & $41 \cdot 61$ & 319 & Average \\
\hline \multirow[t]{2}{*}{$\begin{array}{l}\text { M. P. } \cdots \\
\text { E. O.D. } \\
\text { L. H. } \\
\text { M. P. } \\
\begin{array}{ll}\text { N. } & \cdots \\
\text { J. J. } & \cdots \\
\text { M. H. } & \cdots\end{array}\end{array}$} & \multirow[t]{2}{*}{$\begin{array}{l}\text { F. } \\
\text { F. } \\
\text { M. } \\
\text { F. } \\
\text { M. } \\
\text { F. }\end{array}$} & \multirow[t]{2}{*}{$\begin{array}{l}29 \\
31 \\
33 \\
47 \\
50 \\
59 \\
59\end{array}$} & \multirow[t]{2}{*}{$\begin{array}{l}2495 \\
2347 \\
2347 \\
2347 \\
2347 \\
2347 \\
2147\end{array}$} & $\begin{array}{l}45 \cdot 39 \\
41 \cdot 71 \\
42 \cdot 94 \\
40 \cdot 82 \\
42 \cdot 01 \\
45 \cdot 39 \\
45 \cdot 09\end{array}$ & $\begin{array}{r}- \\
12 \cdot 89 \\
9 \cdot 59 \\
2 \cdot 12 \\
2 \cdot 78 \\
2 \cdot 46 \\
1 \cdot 23\end{array}$ & $\begin{array}{l}\text { Detachment L. retina } \\
\text { Keratitis R.E. } \\
\text { Strabismus } \\
\text { L. excision for in jury } \\
\text { Detachment R. retina } \\
\text { R. corneal ulcer } \\
\text { Iritis L.E. }\end{array}$ \\
\hline & & & & $43 \cdot 34$ & $5 \cdot 18$ & Average \\
\hline & & & & $\begin{array}{r}-36 \cdot 80-49 \\
40 \cdot 82-45\end{array}$ & $\begin{array}{l}0 \cdot 46-6 \\
1 \cdot 23-1\end{array}$ & $\begin{array}{l}\text { Cataract } \\
9 \text { Non-cataract }\end{array}$ \\
\hline
\end{tabular}

N.B.-The same diet was continued in each patient for three successive days for the metabolism experiments, the blood sample for glutathione being taken on the second day.

The diet of 2347 calories contained $66^{\circ} 94 \mathrm{gm}$. protein, 1.935 gm. sulphur, the other diets differed from this only very slightly.

\section{TABLE III}

Blood Glutathione in Relation to the Red Cell Count in Patients on Ordinary Hospital Diet.

\begin{tabular}{|c|c|c|c|c|c|c|}
\hline Patient & Sex & Age & $\begin{array}{l}\text { Red cell } \\
\text { count }\end{array}$ & GSH & $\frac{\text { GSH }}{\text { r.b.c. }}$ & Clinical details \\
\hline $\begin{array}{ll}\text { H. } & \cdots \\
\text { W. H. } & \cdots \\
\text { S. K. } & \cdots \\
\text { J. L. } & \cdots \\
\text { W. R. } & \cdots \\
\text { A. C. } & \cdots \\
\text { E. B. } & \cdots\end{array}$ & \multirow[t]{2}{*}{$\begin{array}{l}\text { M. } \\
\text { M. } \\
\text { M. } \\
\text { F. } \\
\text { M. } \\
\text { F. } \\
\text { F. }\end{array}$} & \multirow[t]{2}{*}{$\begin{array}{l}-66 \\
67 \\
68 \\
70 \\
74 \\
77\end{array}$} & $\begin{array}{l}4,450,000 \\
5,500,000 \\
4,600,000 \\
5,050,000 \\
5,550,000 \\
5,200,000 \\
5,150,000\end{array}$ & $\begin{array}{l}32 \cdot 80 \\
36 \cdot 80 \\
42 \cdot 33 \\
47 \cdot 23 \\
53 \cdot 98 \\
47 \cdot 85 \\
39 \cdot 57\end{array}$ & $\begin{array}{l}7 \cdot 37 \\
6 \cdot 60 \\
9 \cdot 20 \\
9 \cdot 35 \\
9 \cdot 72 \\
9 \cdot 19 \\
7 \cdot 66\end{array}$ & \multirow[t]{2}{*}{ Senile cataract } \\
\hline & & & & $42 \cdot 98$ & $8 \cdot 44$ & \\
\hline \multirow[t]{2}{*}{ 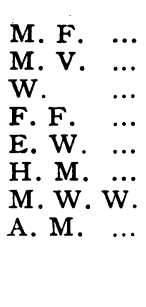 } & \multirow[t]{2}{*}{$\begin{array}{l}\text { M. } \\
\text { M. } \\
\text { M. } \\
\text { M. } \\
\text { F. } \\
\text { F. } \\
\text { F. } \\
\text { M. }\end{array}$} & \multirow[t]{2}{*}{$\begin{array}{l}10 \\
10 \\
20 \\
32 \\
40 \\
43 \\
62 \\
69\end{array}$} & \multirow[t]{2}{*}{$\begin{array}{l}4,100,000 \\
3,750,000 \\
4,750,000 \\
5,600,000 \\
4,700,000 \\
5,600,000 \\
4,300,000 \\
5,600,000\end{array}$} & $\begin{array}{l}33 \cdot 74 \\
37 \cdot 11 \\
36 \cdot 19 \\
54 \cdot 29 \\
35 \cdot 12 \\
46 \cdot 93 \\
46 \cdot 93 \\
58 \cdot 29\end{array}$ & $\begin{array}{r}8 \cdot 02 \\
9 \cdot 89 \\
7 \cdot 61 \\
9 \cdot 69 \\
7 \cdot 40 \\
8 \cdot 38 \\
10 \cdot 93 \\
6 \cdot 68\end{array}$ & \multirow{2}{*}{$\begin{array}{l}\text { Interstitial keratitis } \\
\qquad " \text { " W.R. + ve } \\
\text { Scleral wound" R.E. } \\
\text { Detachment of retina } \\
\text { Secondäry glaucoma, L.E. } \\
\text { Chronic glaucoma, R. and L. } \\
\text { Average }\end{array}$} \\
\hline & & & & $42 \cdot 07$ & 8.56 & \\
\hline
\end{tabular}




\section{TABLE IV}

Blood Glutathione in Patients on Graded and Controlled Diets

\begin{tabular}{|c|c|c|c|c|c|c|c|c|}
\hline Patient & Sex & Age & Diet & $\begin{array}{l}\text { Red cell } \\
\text { count }\end{array}$ & GSH & GSSG & $\frac{\text { GSH }}{\text { r.b.c. }}$ & Clinical details \\
\hline H. T.... & M. & 22 & $\begin{array}{l}\text { H.P. } \\
\text { L.P. } \\
\text { N. }\end{array}$ & $\begin{array}{c}5,600,000 \\
- \\
5,350,000\end{array}$ & $\begin{array}{l}35 \cdot 12 \\
35 \cdot 27 \\
34: 04\end{array}$ & $\begin{array}{l}5 \cdot 98 \\
2 \cdot 46 \\
-\end{array}$ & $\begin{array}{l}6.27 \\
6 \cdot 42 \\
6.36\end{array}$ & $\begin{array}{l}\text { Perforating } \\
\text { injury R.E. }\end{array}$ \\
\hline G. G... & M. & 50 & $\begin{array}{l}\text { L.P. } \\
\text { N. }\end{array}$ & $\begin{array}{c}4,450,000 \\
-\end{array}$ & $\begin{array}{l}37 \cdot 11 \\
36 \cdot 50\end{array}$ & $\begin{array}{c}0.31 \\
-\end{array}$ & $\begin{array}{l}8 \cdot 33 \\
8 \cdot 20\end{array}$ & $\begin{array}{l}\text { Glaucoma, } \\
\text { R. and L. }\end{array}$ \\
\hline G. S... & M. & 68 & $\begin{array}{l}\text { L.P. } \\
\text { N. }\end{array}$ & $\begin{array}{r}5,650,100 \\
-\quad\end{array}$ & $\begin{array}{l}42 \cdot 33 \\
38 \cdot 95\end{array}$ & $\begin{array}{l}2.66 \\
3.07\end{array}$ & $\begin{array}{l}7 \cdot 49 \\
6 \cdot 89\end{array}$ & $\begin{array}{c}\text { Senile cataract, } \\
\text { R. and L. }\end{array}$ \\
\hline G.W... & M. & 72 & $\begin{array}{l}\text { H.P. } \\
\text { L.P. } \\
\text { N. }\end{array}$ & $\begin{array}{c}5,100,000 \\
- \\
5,200,000\end{array}$ & $\begin{array}{l}29 \cdot 44 \\
37 \cdot 41 \\
38 \cdot 34 \\
\end{array}$ & $\begin{array}{l}8 \cdot 90 \\
3 \cdot 69 \\
4 \cdot 60\end{array}$ & $\begin{array}{l}5 \cdot 77 \\
7 \cdot 07 \\
7 \cdot 03 \\
\end{array}$ & $\begin{array}{c}\text { Senile cataract, } \\
\text { R. and I. }\end{array}$ \\
\hline D. T.... & M. & 73 & $\begin{array}{l}\text { H.P. } \\
\text { L.P. }\end{array}$ & $\begin{array}{r}3,250,000 \\
-\quad\end{array}$ & $\begin{array}{l}26 \cdot 68 \\
26 \cdot 07\end{array}$ & $\begin{array}{l}4 \cdot 00 \\
1 \cdot 61\end{array}$ & $\begin{array}{l}8.21 \\
8.02\end{array}$ & $\begin{array}{l}\text { Senile cataract, } \\
\quad K \text {. and } L .\end{array}$ \\
\hline
\end{tabular}

N.B.-Each diet was continued for three successive days, one day's interval being allowed between the change from one diet to the next. Blood was taken on the second day for estimation and cell count.

Daily diet :

High protein (H.P.)

Low protein (L.P.)

Normal (N.)

\section{Protein}

$107 \cdot 42 \mathrm{gm}$

$\begin{array}{rr}\cdots & 107 \cdot 42 \\ \ldots & 33 \cdot 23\end{array}$

.... $67 \cdot 87$

$\begin{array}{lc}\text { Sulphur } & \text { Calories } \\ 3.987 \mathrm{gm} . & 2325 \\ 0.931 & 2328 \\ 1.863 & 2261\end{array}$

2328

2261

TABLE V

Example of Controlled Normal Diet of 2347 Calories PER DIEM

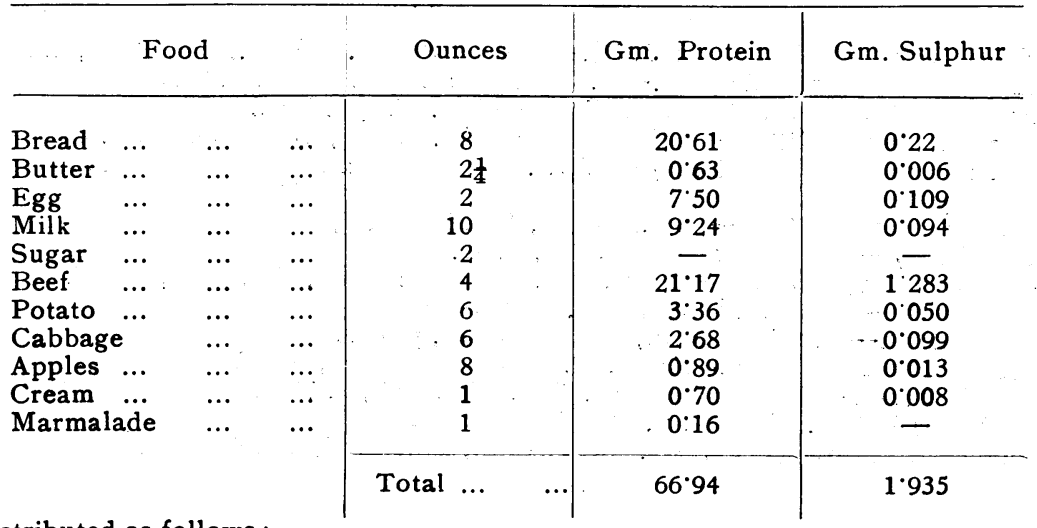

distributed as follows:-

Breakfast-Bread 2 oz., butter $\frac{1}{2}$ oz., 1 egg boiled.

Lunch-Bread 1 oz., butter 1 oz.

Dinner-Beef 4 oz. (sirloin steak, minced raw, weighed and cooked with water), potato $6 \mathrm{oz}$. (weighed raw after peeling, steamed), cabbage $6 \mathrm{oz}$. (weighed raw, and steamed), apples $8 \mathrm{oz}$. (weighed after peeling, stewed with $1 \mathrm{oz}$. sugar), cream $1 \mathrm{oz}$.

Tea-Bread 3 oz., butter 3 oz., marmalade 1 oz.

Supper-Bread 2 oz., butter $\frac{1}{2}$ oz., milk $5 \mathrm{oz}$.

Fluid not less than $2 \frac{1}{2}$ pints as tea or coffee allowed for the day, together with sugar $1 \mathrm{oz}$. , and milk $5 \mathrm{oz}$. 


\section{Summary of Results}

(1) There is no marked variation in the reduced glutathione of the blood, with age or diet, or in senile cataract as compared with other ocular conditions. The range for all cases of ocular disease is within the normal.

(2) In comparison with reduced glutathione, the oxidised glutathione shows considerable variation, especially in non-cataract cases, but no significant change.

(3) The factor GSH/r.b.c. is not raised above the normal value in ocular disease, and shows the same range in senile cataract as in other ocular conditions, including active keratitis (cf. Vele).

\section{Comment}

Although these results are negative, it is particularly interesting to find that the blood glutathione, like the blood calcium, remains constant over a certain range in a variety of conditions of age and disease. Moreover, in ocular disease, it appears to be unaffected by the sulphur metabolism of the body, even when there is a large variation in the amount of sulphur which is being ingested. This is probably true also for normal subjects.

In conclusion, I am indebted to the Birmingham and Midland Eye Hospital for a research grant covering the cost of these investigations. I am grateful to my colleagues on the staff for allowing me free access to their cases, and to Miss Marshall for doing the blood-counts.

\section{REFERENCES.}

Achard, Levy and Guthmann (1932).-Bull. de l'acad. de med., Vol. CVII, p. 366. Benedict and Gottschall (1932).-Jl. Biol. Chem., Vol. XCIX, p. 729.

Bourne and Campbell.-To be published-Brit. Jl. of Ophthal.

Euler and Martius (1933).-Zeitschr.f. physiol. Chem., Vol. CCXXII, p. 65.

Giordano and Battistini (1933). -Giorn. r. accad.di med. di Torino, Vol. XCIV, p. 241.

Groen and Meyer (1932).-Biochem. Jl., Vol. XXVI, p, 624

Lewis (1935).-Jl. of Nutrition, Vol. X, p. 99.

Loomis and Bogen (1934).-Amer. Rev. of Tuberculosis, Vol. XXX, p. 505.

Lucca (1933).-Pediatrica, Vol. XLI, p 499.

Mason (1928).-Jl. Biol. Chem., Vol. LXXXVI, p. 629.

Oberst and Woods (1935).-Amer. Jl. Obst. and Gynec., Vol. XXX, p. 232.

Senturia (1934).-Jl. Lab. and Clin. Med., Vol. XIX, p. 1151.

Vele (1933). -Ann. di Oftalm., Vol. LXI, p. 170.

Woodward and Fry (1932).-Ji. Biol. Chem., Vol. XCVII, p. 465. 